\title{
Efficacy of zinc oxide nanoparticles on hepatocellular carcinoma- induced biochemical and trace element alterations in rats
}

\author{
Samir A. E. Bashandy ${ }^{*}$, Omar A. H. Ahmed-Farid ${ }^{2}$, Sherif Abdelmottaleb Moussa ${ }^{3}$, Enayat A. Omara ${ }^{4}$, Gehad A. Abdel Jaleel ${ }^{1}$, \\ Fatma A. A. Ibrahim ${ }^{3}$ \\ ${ }^{1}$ Pharmacology Department, National Research Centre, Cairo, Egypt. \\ ${ }^{2}$ Physiology Department, National Organization for Drug Control and Research, Cairo, Egypt. \\ ${ }^{3}$ Biophysics Group, Department of Biochemistry, Genetic Engineering and Biotechnology Division, National Research Centre, Cairo, Egypt. \\ ${ }^{4}$ Pathology Department, National Research Centre, Cairo, Egypt.
}

\begin{tabular}{|c|c|}
\hline ARTICLE INFO & ABSTRACT \\
\hline $\begin{array}{l}\text { Received on: } 30 / 11 / 2020 \\
\text { Accepted on: } 23 / 01 / 2021 \\
\text { Available online: } 05 / 05 / 2021\end{array}$ & $\begin{array}{l}\text { The purpose of this study is to evaluate the probable roles of zinc oxide nanoparticles (ZnO-NPs) at a dose level } \\
\text { of } 5 \mathrm{mg} \text { or } 10 \mathrm{mg} / \mathrm{kg} \text { as antitumor in hepatocellular carcinoma (HCC) animal model. HCC was induced in rats by } \\
\text { using diethylnitrosamine and carbon tetrachloride. The treatment of HCC rats with ZnO-NPs alleviated the significant } \\
\text { increase in cancer markers, alpha-fetoprotein (AFP), glypican-3 (GPC3), and Vascular Endothelial Growth Factor }\end{array}$ \\
\hline $\begin{array}{l}\text { Key words: } \\
\text { Zinc oxide nanoparticles, } \\
\text { hepatocellular carcinoma, } \\
\text { trace elements, anti- } \\
\text { inflammatory, oxidative } \\
\text { stress. }\end{array}$ & $\begin{array}{l}\text { (VEGF). The treatment of HCC rats with ZnO-NPs relieved the increase in liver enzymes and histopathological } \\
\text { changes. Also, ZnO-NPs lessened the increase in the inflammatory markers. Moreover, the treatment of HCC rats } \\
\text { with ZnO-NPs led to a significant decline in hepatic malondialdehyde (MDA) and 8-hydroxy-2'-deoxyguanosine and } \\
\text { a significant increase in reduced form of glutathione and DNA content of hepatic cells as compared to the HCC group. } \\
\text { Additionally, ZnO-NPs prevented the significant increase in hepatic copper and manganese levels or the decrease in } \\
\text { zinc level in rats with HCC. Furthermore, ZnO-NPs can modulate plasma glucose level and lipid profile associated } \\
\text { with improved hepatic mucopolysacchrides and ATP that altered in the HCC group. In conclusion, the treatment of } \\
\text { HCC rats with ZnO-NPs offered an anticancer remedy that may be considered as a new trend for control HCC. }\end{array}$ \\
\hline
\end{tabular}

\section{INTRODUCTION}

Hepatocellular carcinoma (HCC) is the most prevalent disease worldwide (Torre et al., 2012). Many risk factors such as chronic alcohol consumption, viral hepatitis and fatty liver disease have been participated in HCC associated fibrosis and cirrhosis (Parikh and Hyman, 2007). Oxidative stress and cytokine/ adipocytokine pathways may involve nonalcoholic fatty liver disease-related HCC pathogenesis which likely participates in the development of HCC (Starley et al., 2010). Cancer cells directed metabolism in favor of their demand. Metabolic modifications allow tumor growth, proliferation, and survival as they supply cancer cells with energy and macromolecule biosynthesis.

\section{${ }^{*}$ Corresponding Author}

Samir A. E. Bashandy, Pharmacology Department, National Research Centre, Cairo, Egypt.E-mail: Bashandysamir@gmail.com
Enhanced consumption of glucose, a common feature of cancers, reinforces the formation of mediate compounds for the induction of lipids, proteins, and nucleic acids synthesis. Otherwise, increased glutamine uptake and glutaminolysis permit cancer cells to accomplish intermediates in the Krebs cycle that are directed toward biosynthetic reactions (Schulze and Harris, 2012). It was reported that hypoglycemia in $\mathrm{HCC}$ was due to a rise in glucose consumption by a rapid-growing tumor (Sharma et al., 2014). Various cancer cells have been shown to promote the activity of mevalonate pathway enzymes, a precursor for cholesterol synthesis (Mullen et al., 2016). The metabolic reprogramming in HCC includes mitochondrial malfunction. The elevated free radicals production and the decrease in adenosine triphosphate generation may participate in the HCC development (Hsu et al., 2013).

Nanomedicine may reflect a recent direction in the universe. It is interested in the biomedical accomplishment of nanotechnology in the rapid identification and remedy of diseases. 
In newly years, many scientists attempt to use the distinctive characters of nanoparticles, particularly zinc oxide nanoparticles (ZnO-NPs) in the management of some diseases (McNeil, 2009). It was reported that $\mathrm{ZnO}-\mathrm{NPs}$ resemble biomolecules in their activity; therefore, they can maintain cellular homeostasis (Vizirianakis, 2011). Traditional treatment of cancer as chemotherapy exhibited unfavorable effects and affects most cells. The most unfavorable effects of cancer chemotherapy are nausea, hair loss, mouth sores, memory impairment, diarrhea, headache, dry mouth, fatigue, abdominal cramps, and vomiting (Aslam et al., 2014). Therefore, searching for other replacement medication for cancer has become urgent (Gowda et al., 2013). ZnO-NPs showed the cytotoxic effect on different cancer cell lines (Elsayed et al., 2020). ZnONPs represented a promising preclinical anticancer efficacy in $\mathrm{HCC}$ and could be considered as a novel strategy for the treatment of HCC in clinical practices (Hassan et al., 2017). No previous studies on the effect of zinc nanoparticles on trace elements in HCC have been notified. Therefore, the target of the present study is the evaluation of the zinc nanoparticles in vivo as medication for HCC via investigation cancer or inflammatory markers, oxidative stress parameters, and hepatic trace elements. Zinc nanoparticles were used as they have new biomedical applications and display potential toxicity against some cancerous cells.

\section{MATERIALS AND METHODS}

\section{Chemicals}

Methanol (HPLC grade) was secured from Loba Co., India. Perchloric acid was bought from Loba Co., India. Sulphosalsilic acid and P-amino benzyl glutamate and pyrogallol were purchased from TMMEDIA Co., India. The 1,1,3,3-tetraethoxypropane, reduced form of glutathione (GSH), and oxidized form of glutathione (GSSG) were gotten from Sigma Aldrich (USA). Other used chemicals were of purity grade and were bought from known supplies.

\section{Synthesis of $\mathrm{ZnO}$-NPs}

For the synthesis of the samples, we dissolved $2 \mathrm{~g}$ of zinc acetate dehydrate in $14 \mathrm{ml}$ of methanol, under magnetic stirring for 2 hours. Then, the resulting solution underwent rapid drying to obtain powder aerogels. Furthermore, we conducted drying in supercritical conditions of ethanol at $250^{\circ} \mathrm{C}$, with a heating rate of $45^{\circ} \mathrm{C} /$ hours. The secured powder was placed in an oven at $500^{\circ} \mathrm{C}$ for 2 hours to get $\mathrm{ZnO}-\mathrm{NPs}$ (About $50 \mathrm{~nm}$ ). Nanopowder was recognized by $\mathrm{x}$-ray diffraction. Moreover, the nanopowder was characterized according to morphology and structure properties (Omri et al., 2016)

\section{Preparation of $\mathrm{ZnO}$-NPs solution}

The nanoparticles of zinc oxide were added to $1 \%$ sodium carboxymethyl cellulose as a stabilizer, moved by a magnetic stirrer for 5 minutes, and followed by exposure to ultrasonic vibration for 15 minutes (Wang et al., 2008).

\section{Induction of $\mathrm{HCC}$}

The rats were injected IP with a single dose of DENA (200 mg/kg body weight). After 2 weeks, animals received $\mathrm{CCl}_{4}(3$ $\mathrm{ml} / \mathrm{kg}$ ) dissolved in corn oil ( $1: 1$ volume) injected subcutaneously once a week for 6 weeks (Singh et al., 2009).

\section{Ethics statement}

Animal handling was executed following the guidance of Laboratory Animals of the National Institutes of Health (NIH publication No. 85-23, revised 1996) and National Research Centre (NRC) in Egypt with ethical approval No. 19218.

\section{Animals and treatment}

Male Wistar rats (weighing 150-170 g and 3 months old) were brought from National Research Centre (NRC) of Egypt. They were given freely standard pellet diet and water. The animals remained at adjusted temperature $\left(22^{\circ} \mathrm{C} \pm 2^{\circ} \mathrm{C}\right)$ with equal light and dark cycle. Thirty-two rats were sorted into the following groups:

Group 1. Normal rats served as control injected with the same volume of vehicle $(0.2 \mathrm{ml} 1 \%$ sodium carboxymethyl cellulose) IP.

Group 2. Rats with HCC injected with the same volume of vehicle IP.

Group 3 and 4. Rats with HCC injected IP with 5 and 10 $\mathrm{mg} / \mathrm{kg} \mathrm{ZnO}-\mathrm{NPs}$ daily for 8 weeks (Bashandy et al., 2018).

\section{Samples collection}

The blood was gathered after 2 months from rats killed under ether anesthesia and plasma was separated and kept at $-30^{\circ} \mathrm{C}$. The liver samples were handled for histological study and for evaluation of malondialdehyde (MDA), reduced glutathione (GSH), oxidized glutathione (GSSG), superoxide dismutase (SOD), catalase (CAT), nitric oxide (NO), tumor necrosis factor-alpha (TNF- $\alpha$ ), and coenzyme Q10 (CoQ10). Homogenized liver samples were obtained and the supernatant was stored at $-80^{\circ} \mathrm{C}$ until assay.

\section{Determination of cancer markers in plasma}

Alpha-fetoprotein (AFP) was determined by ELISA technique using kits get from Sunlong Biotech Co. Ltd., China, while VEGF and glypican-3 (GPC3) were assayed by the same technique using kits purchased from Lifespan Biosciences, Inc., USA.

\section{Hepatic oxidative stress parameters}

Hepatic MDA, GSH, GSSG, NO, and CoQ10 (Karatas et al., 2002; Papadoyannis et al., 1999; Yoshida, 1996; Yubero et al., 2014) levels were evaluated by the HPLC system of Agilent HP 1200 series (USA). SOD activity was assayed in the homogenate by the method of Marklund and Marklund (1974).

\section{Determination of hepatic ATP and 8-hydroxy-2'- deoxyguanosine (8-OHdG)}

Moreover, the detection of ATP and 8-OHdG was carried out by HPLC (Lodovici et al., 1997; Teerlink et al., 1993;,).

\section{Anti-inflammatory markers}

Plasma C-reactive protein (CRP) and interleukin 6 (IL6) were assayed by immunoassay (ELISA) using kits get from Sunlong Biotech Co. Kit, China. Tumor necrosis factor-alpha 
(TNF- $\alpha$ ) was assayed using an enzyme immunoassay kit produced by R\&D Systems (USA).

\section{Liver function and lipid profile tests}

Plasma aspartate aminotransferase (AST), alanine aminotransferase (ALT), total bilirubin, total protein, glucose, and lipid profile were evaluated calorimetrically using kits of Salucea Company, Netherlands, while gamma-glutamyl transferase (GGT) was determined kinetically using kits produced by Egyptian company for biotechnology.

\section{Determination of hepatic trace elements}

Hepatic zinc, copper, and manganese concentrations ( $\mu \mathrm{g} / \mathrm{g}$ dry tissue) were evaluated by the use of atomic absorption spectrophotometry (PyeUnicam, Cambridge, UK). Samples of tissues were put in an oven and dried. Certain weight of dried samples was digested with nitric acid and perchloric acid $(2: 1$, $v / v$ ) in a sand bath and wet residues were watered to $5 \mathrm{ml}$ and centrifuged.

\section{Histological analysis}

After the fixation of liver samples, they were stained with hematoxylin and eosin for investigation of the histopathological changes. Moreover, some liver sections were stained with Masson trichrome stain which was used for demonstrating the collagen fibers.

\section{Histochemical examination}

Sections of $5 \mu \mathrm{m}$ thickness produced were stained with periodic acid Schiff (PAS) to demonstrate muco polysaccharides
(MPS) or with Feulgen stain for DNA. Both Feulgen stain (DNA) and PAS sections are subjected to measurement of optical density using an image analyzer (Leica Qwin 500).

\section{Statistical analysis}

The rough data were analyzed statistically at $p<0.01$ using analysis of variance and LSD comparison test by using SPSS software, version 21 .

\section{RESULTS}

\section{Cancer markers}

Table 1 showed that the treatment to hepatocarcinoma rats with of ZnO-NPs significantly $(p<0.01)$ lowered the increase in plasma levels of cancer markers ( $\alpha$-fetoprotein, GPC3, and VEGF) when compared with the HCC group. The effect of $\mathrm{ZnO}$ NPs on all parameters tested or histopathological study is dose dependent; the effect of high dose is more pronounced than low dose.

\section{Hepatic oxidative stress parameters}

The oxidative stress parameters are affected by HCC as manifested by a significant $(p<0.01)$ rising of MDA, GSSG, $\mathrm{SOD}$, and NO levels (Table 2) in comparison with the control group. Otherwise, hepatic GSH and CoQ10 lowered significantly $(p<0.01)$ relative to the control. In the HCC rats treated with ZnO-NPs, GSH and CoQ10 were elevated significantly $(p<0.01)$, while MDA and NO were diminished significantly $(p<0.01)$ as compared to the HCC group.

Table 1. Effect of zinc oxide nanoparticles on plasma AFP, GPC3, and VEGF in HCC rat model.

\begin{tabular}{ccccc}
\hline Treatment parameter & Control & DENA & DENA + ZnO-NPs L & DENA+ZnO-NPs H \\
\hline AFP $(\mathrm{ng} / \mathrm{ml})$ & $8.45 \pm 0.37$ & $33.64 \pm 1.26^{\mathrm{a}}$ & $25.08 \pm 0.75^{\mathrm{ab}}$ & $18.49 \pm 0.58^{\mathrm{abc}}$ \\
GPC3 $(\mathrm{pg} / \mathrm{ml})$ & $11.04 \pm 0.26$ & $40.52 \pm 2.31^{\mathrm{a}}$ & $32.07 \pm 0.88^{\mathrm{ab}}$ & $24.11 \pm 0.63^{\mathrm{abc}}$ \\
VEGF $(\mathrm{ng} / \mathrm{l})$ & $53.64 \pm 2.94$ & $191.34 \pm 7.83^{\mathrm{a}}$ & $140.11 \pm 4.68^{\mathrm{ab}}$ & $116.73 \pm 5.29^{\mathrm{abc}}$ \\
\hline
\end{tabular}

Each value is the mean $\pm \mathrm{SE} ; n=8$

$\mathrm{L}=5 \mathrm{mg} / \mathrm{Kg} ; \mathrm{H}=10 \mathrm{mg} / \mathrm{Kg}$; AFP = alpha-fetoprotein; GPC3 = glypican-3; VEGF = vascular endothelial growth factor.

a Significant difference compared to the control group at $p<0.01$.

${ }^{\text {b}}$ Significant difference compared to the HCC group at $p<0.01$.

'Significant difference compared to the HCC $+\mathrm{ZnO}-\mathrm{NPs}$ L group at $p<0.01$.

Table 2. Effect of zinc oxide nanoparticles on hepatic oxidative stress parameters in HCC rat model.

\begin{tabular}{ccccc}
\hline Treatment Parameter & Control & HCC & HCC + ZnO-NPs L & HCC + ZnO-NPs H \\
\hline MDA $(\mathrm{nmol} / \mathrm{g})$ & $36.63 \pm 1.00$ & $56.15 \pm 1.96^{\mathrm{a}}$ & $45.75 \pm 1.19^{\mathrm{ab}}$ & $40.31 \pm 2.06^{\mathrm{b}}$ \\
GSH $(\mu \mathrm{mol} / \mathrm{g})$ & $4.25 \pm 0.07$ & $2.25 \pm 0.15^{\mathrm{a}}$ & $2.60 \pm 0.12^{\mathrm{ab}}$ & $3.47 \pm 0.17^{\mathrm{abc}}$ \\
GSSG $(\mu \mathrm{mol} / \mathrm{g})$ & $0.32 \pm 0.04$ & $0.41 \pm 0.01^{\mathrm{a}}$ & $0.39 \pm 0.02$ & $0.34 \pm 0.01^{\mathrm{b}}$ \\
SOD $(\mathrm{U} / \mathrm{G})$ & $44.38 \pm 0.86$ & $52.82 \pm 1.20^{\mathrm{a}}$ & $45.81 \pm 1.70$ & $46.53 \pm 1.75$ \\
NO $(\mu \mathrm{mol} / \mathrm{g})$ & $0.59 \pm 0.03$ & $1.00 \pm 0.032^{\mathrm{a}}$ & $0.86 \pm 0.02^{\mathrm{ab}}$ & $0.65 \pm 0.02^{\mathrm{bc}}$ \\
CoQ10 $(\mathrm{nmol} / \mathrm{g})$ & $1.18 \pm 0.04$ & $0.62 \pm 0.03^{\mathrm{a}}$ & $0.97 \pm 0.06^{\mathrm{ab}}$ & $1.23 \pm 0.04^{\mathrm{bc}}$ \\
\hline
\end{tabular}

Each value is the mean $\pm \mathrm{SE} ; n=8$.

$\mathrm{L}=5 \mathrm{mg} / \mathrm{Kg} ; \mathrm{H}=10 \mathrm{mg} / \mathrm{Kg}$; MDA = malondialdehyde; $\mathrm{GSH}=$ reduced form of glutathione; GSSG = oxidized form of glutathione;

$\mathrm{SOD}=$ superoxide dismutase; $\mathrm{NO}=$ nitric oxide; CoQ10 = coenzyme Q10.

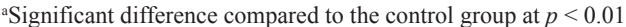

bSignificant difference compared to the HCC group at $p<0.01$.

'Significant difference compared to the HCC $+\mathrm{ZnO}-\mathrm{NPs} \mathrm{L}$ group at $p<0.01$. 


\section{Anti-inflammatory markers}

As displayed from Figure 1, the treatment of HCC rats with ZnO-NPs significantly $(p<0.01)$ inhibited the increase in plasma CRP, IL-6, and TNF- $\alpha$ levels when compared with the HCC group.

\section{Glucose, mucopolysacchrides (MPS), and ATP}

The injection of $\mathrm{HCC}$ rats with ZnO-NPs mitigated significantly $(p<0.01)$ the decrease in plasma glucose or hepatic MPS, and ATP levels (Fig. 2) as compared with the HCC group.

\section{Liver function and lipid profile tests}

The values of liver enzymes and bilirubin in $\mathrm{HCC}+$ $\mathrm{ZnO}$-NPs were significantly $(p<0.01)$ lower than those of the
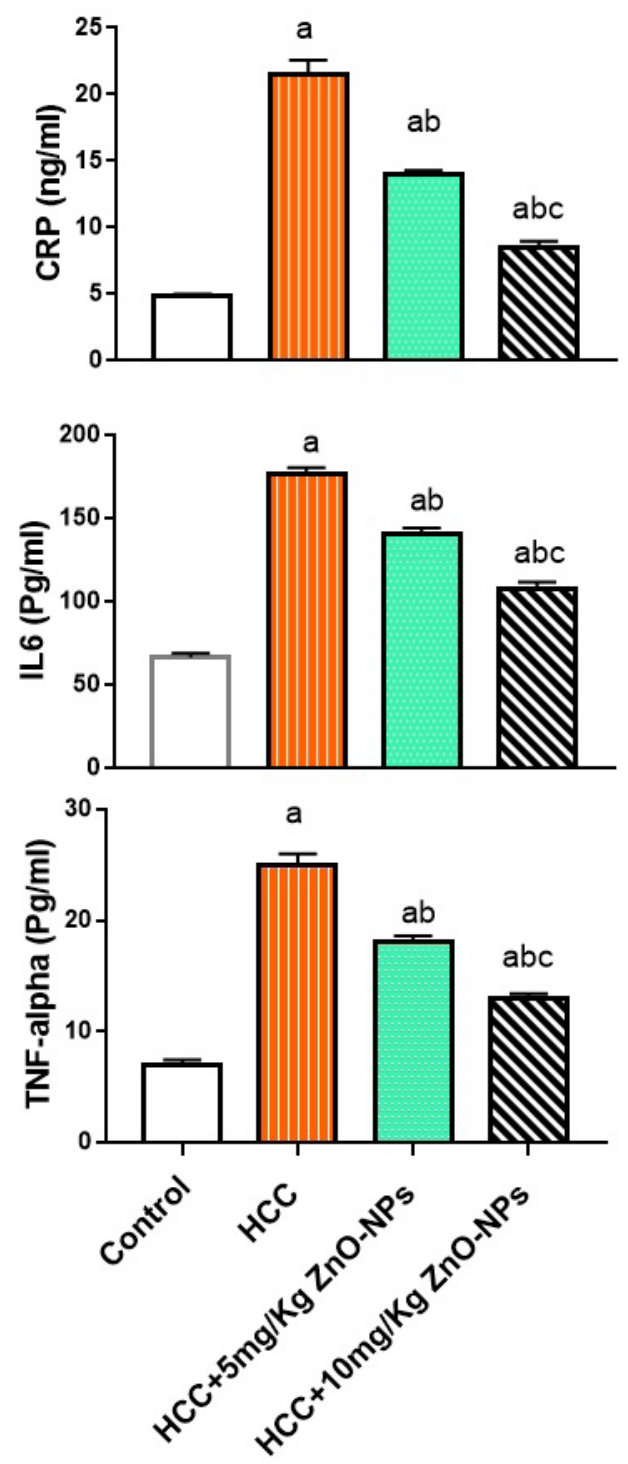

Figure 1. Plasma inflammatory markers in various groups; $\mathrm{CRP}=\mathrm{C}$-reactive protein; IL-6 = interleukin 6; TNF-alpha = tumor necrosis factor-alpha. (a): significant difference from the control group, (b): significant difference from the $\mathrm{HCC}$ group, and (c): significant difference from the $\mathrm{HCC}+5 \mathrm{mg} / \mathrm{Kg} \mathrm{ZnO}-\mathrm{NPs}$ (zinc oxide nanoparticles) group at $p \leq 0.01$. Each value is the mean $\pm \mathrm{SE} ; n=8$.
HCC group (Table 3). Moreover, plasma cholesterol, triglycerides, and low-density lipoprotein (LDL) levels in the HCC group (Table 4) were significantly increased $(p<0.01)$ while highdensity lipoprotein (HDL) was lowered significantly $(p<0.01)$ as compared to control. The lipid profile parameters were improved by $\mathrm{ZnO}-\mathrm{NPs}$ treatments. The protein level in $\mathrm{HCC}+\mathrm{ZnO}-\mathrm{NPs}$ did not change significantly as compared to control.

\section{Hepatic trace elements}

The hepatic levels of zinc, copper, and manganese in rats with $\mathrm{HCC}$ treated with $\mathrm{ZnO}-\mathrm{NPs}$ were presented in Figure. 3. The levels of zinc were significantly $(p<0.01)$ lower in rats with HCC in comparison to controls (125 versus. $153 \mu \mathrm{g} / \mathrm{g})$. The hepatic copper content was significantly higher $(p<0.01)$ in rats with HCC than controls (47.69 versus. $17.65 \mu \mathrm{g} / \mathrm{g}$ ) as well as
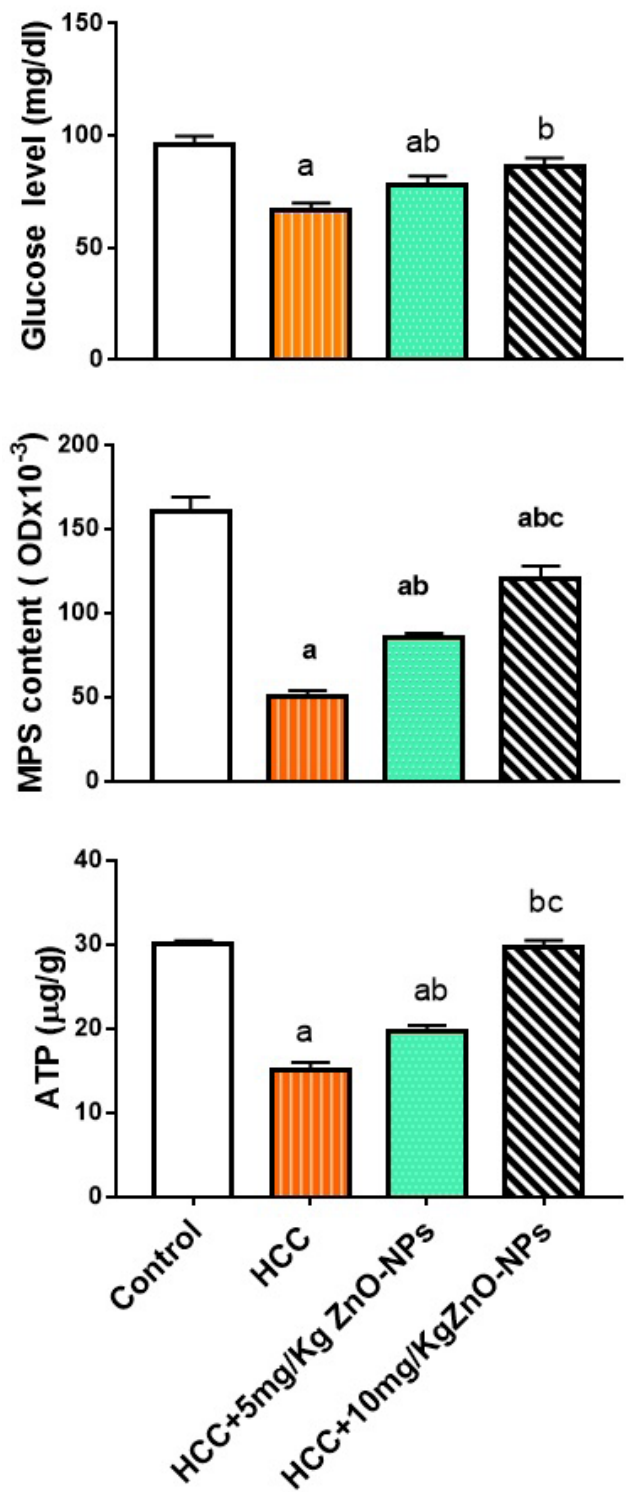

Figure 2. Plasma glucose, hepatic MPS (mucopolysaccharides), and ATP (adenosine triphosphate) levels in various groups. (a): significant difference from the control group, (b): significant difference from the HCC group, and (c): significant difference from the $\mathrm{HCC}+5 \mathrm{mg} / \mathrm{Kg} \mathrm{ZnO}-\mathrm{NPs}$ (zinc oxide nanoparticles) group at $p \leq 0.01$. Each value is the mean $\pm \mathrm{SE} ; n=8$. 
Table 3. Effect of zinc oxide nanoparticles on liver function in $\mathrm{HCC}$ rats.

\begin{tabular}{|c|c|c|c|c|}
\hline Treatment Parameter & Control & $\mathrm{HCC}$ & $\mathrm{HCC}+\mathrm{ZnO}$-NPs L & HCC + ZnO-NPs H \\
\hline $\operatorname{AST}(\mathrm{U} / \mathrm{ml})$ & $139.7 \pm 5.10$ & $195.5 \pm 1.80^{\mathrm{a}}$ & $148.2 \pm 2.10^{\mathrm{b}}$ & $146.7 \pm 6.9^{b}$ \\
\hline $\operatorname{ALT}(\mathrm{U} / \mathrm{ml})$ & $42.2 \pm 3.50$ & $113.5 \pm 2.70^{\mathrm{a}}$ & $76.1 \pm 3.5^{\mathrm{ab}}$ & $70.6 \pm 6.9^{\mathrm{ab}}$ \\
\hline GGT (U/L) & $6.73 \pm 0.22$ & $37.95 \pm 1.24^{\mathrm{a}}$ & $25.00 \pm 0.61^{\mathrm{ab}}$ & $17.39 \pm 0.58^{\mathrm{abc}}$ \\
\hline $\mathrm{T}$ Bil (mg/dl) & $1.8 \pm 0.09$ & $3.7 \pm 0.31^{\mathrm{a}}$ & $1.90 \pm 0.06^{\mathrm{b}}$ & $1.85 \pm 0.07^{\mathrm{b}}$ \\
\hline Protein $(\mathrm{g} / \mathrm{dl})$ & $7.80 \pm 0.15$ & $8.90 \pm 0.37^{\mathrm{a}}$ & $7.90 \pm 0.50$ & $7.50 \pm 0.5$ \\
\hline \multicolumn{5}{|c|}{$\begin{array}{l}\text { Each value is the mean } \pm \mathrm{SE} ; n=8 \text {. } \\
\mathrm{L}=5 \mathrm{mg} / \mathrm{Kg} ; \mathrm{H}=10 \mathrm{mg} / \mathrm{Kg} ; \mathrm{AST}=\text { aspartate aminotransferase; ALT }=\text { alanine aminotransferase; GGT }=\text { gamma-glutamyl } \\
\text { transferase; T Bil: total bilirubin. } \\
\text { aSignificant difference compared to the control group at } p<0.01 . \\
\text { bignificant difference compared to the HCC group at } p<0.01 . \\
\text { 'Significant difference compared to the HCC }+ \text { ZnO-NPs L group at } p<0.01 .\end{array}$} \\
\hline
\end{tabular}

Table 4. Effect of zinc oxide nanoparticles on plasma lipid profile in HCC rat model.

\begin{tabular}{lcccc}
\hline Treatment Parameter & Control & HCC & HCC + ZnO-NPs L & HCC + ZnO-NPs H \\
\hline Cholesterol (mg/dl) & $90.50 \pm 0.85$ & $224.6 \pm 8.60^{\mathrm{a}}$ & $193.8 \pm 60.4^{\mathrm{ab}}$ & $143.6 \pm 5.00^{\mathrm{abc}}$ \\
Triglyceride $(\mathrm{mg} / \mathrm{dl})$ & $67.00 \pm 1.50$ & $192.1 \pm 4.7^{\mathrm{a}}$ & $128.3 \pm 6.6^{\mathrm{b}}$ & $119.7 \pm 7.50^{\mathrm{ab}}$ \\
HDL $(\mathrm{mg} / \mathrm{dl})$ & $73.7 \pm 3.3$ & $46.20 \pm 1.13^{\mathrm{a}}$ & $66.5 \pm 2.80^{\mathrm{b}}$ & $68.9 \pm 2.15^{\mathrm{b}}$ \\
LDL $(\mathrm{mg} / \mathrm{dl})$ & $16.94 \pm 0.8$ & $98.20 \pm 1.50^{\mathrm{a}}$ & $56.00 \pm 2.08^{\text {ab }}$ & $40.56 \pm 1.60^{\mathrm{ab}}$ \\
\hline Each value is the mean $\pm \mathrm{SE} ; n=8$. & \\
$\mathrm{L}=5 \mathrm{mg} / \mathrm{Kg} ; \mathrm{H}=10 \mathrm{mg} / \mathrm{Kg} ; \mathrm{HDL}=$ high-density lipoprotein; LDL $=$ low-density lipoprotein. \\
aSignificant difference compared to the control group at $p<0.01$. \\
'Significant difference compared to the HCC group at $p<0.01$. \\
'Significant difference compared to the HCC + ZnO-NPs L group at $p<0.01$. high- and low-.
\end{tabular}

manganese concentration $(17.33 \mu \mathrm{g} / \mathrm{g}$ versus. $5.34 \mu \mathrm{g} / \mathrm{g})$. Injection of $\mathrm{ZnO}-\mathrm{NPs}$ to HCC rats caused a notable increase $(p<0.01)$ in zinc and a remarkable decrease $(p<0.01)$ in copper or manganese when compared with the HCC group.

\section{Hepatic DNA content and 8-OHdG}

The DNA content in liver cells (Fig. 4) of all groups showed a grand decrease $(p<0.01)$ relative to control, but it increased significantly in $\mathrm{HCC}$ rats injected with any doses of $\mathrm{ZnO}-\mathrm{NPs}$ as compared to the HCC group. As demonstrated in Figure 4, the 8-OHdG level in $\mathrm{HCC}+\mathrm{ZnO}-\mathrm{NPs}$ groups lowered significantly $(p<0.01)$ when compared to the HCC group.

\section{Histopathological results}

The hepatic cells of rats with HCC showed loss of hepatic lobular construction, ballooning appearance, malformed cord arrangement, defective sinusoids, pyknotic nuclei, and pronounced steatosis. Also, portal tracts were extended with massive necrosis, inflammatory cell infiltration, and fibrous tissue with periportal and pericellular fibrosis (Fig. 5B) as compared to liver control sections (Fig. 5A).

Treatments of HCC rats with $5 \mathrm{mg} / \mathrm{kg} \mathrm{ZnO}-\mathrm{NPs}$ preserved partly the hepatic normal architecture. The hepatocytes were still with a moderate degree of steatosis. Inflammation cell infiltration and portal tracts to pericellular were also noticed as shown in Figure 5C.

Inflammation cell infiltration, swollen hepatocytes, and dilated central vein were also present in the livers of the HCC + high dose $\mathrm{ZnO}-\mathrm{NPs}$ (10 mg/kg) group but they were notably reduced in extent fibrous tissue and were less frequent compared to the HCC group (Fig. 5D).

\section{Masson's trichrome staining}

The microscopic investigation of liver tissue of the HCC group revealed multiple fibrotic extensive fibrosis (Fig. 6B) as compared to the control group (Fig. 6A). Fibrotic lesions were mild in the livers of the groups treated with low and high doses of ZnO-NPs compared to the HCC group (Figs. 6C and D).

\section{DISCUSSION}

HCC resembles the main health global dilemma. It is the most existing cancer in the world (Ferlay et al., 2015). In Egypt, HCC incidence is more in males than in females and hepatitis C participates in HCC development (Zekri et al., 2008). Many researchers try to find a new plan for control HCC. In the present work, our goal is the appreciation of the effectiveness of $\mathrm{ZnO}-\mathrm{NPs}$ on the treatment of $\mathrm{HCC}$ in male rats. Our results demonstrated the anticancer activity for $\mathrm{ZnO}-\mathrm{NPs}$ as evidenced by a reduction in the elevation of AFP, GPC3, and VEGF (cancer markers). It has appeared that $\mathrm{ZnO}-\mathrm{NPs}$ have an antiangiogenesis effect as the VEGF level (an angiogenic marker) is decreased by $\mathrm{ZnO}-\mathrm{NPs}$ treatment to rats with HCC. Furthermore, $\mathrm{ZnO}-\mathrm{NPs}$ were confirmed by the Food and Drug Administration as a recent and efficient therapy for cancer (Shen et al., 2013). It has been reported that $\mathrm{ZnO}-\mathrm{NPs}$ significantly decreased the elevated serum levels of HCC-related tumor marker AFP, alpha-l- fucosidase, and the apoptotic marker caspase- 3 and also significantly reduced oxidative stress markers which are in agreement with previous results (Hassan et al., 2017). ZnO-NPs can yield toxicity toward cancer cells via the production of free radicals and oxidative stress, in addition to the motivation of apoptosis (Vinardell and Mitjans, 2015). ZnO produced much higher cytotoxicity than nonmetal nanoparticles. This was significantly approved by glutathione 

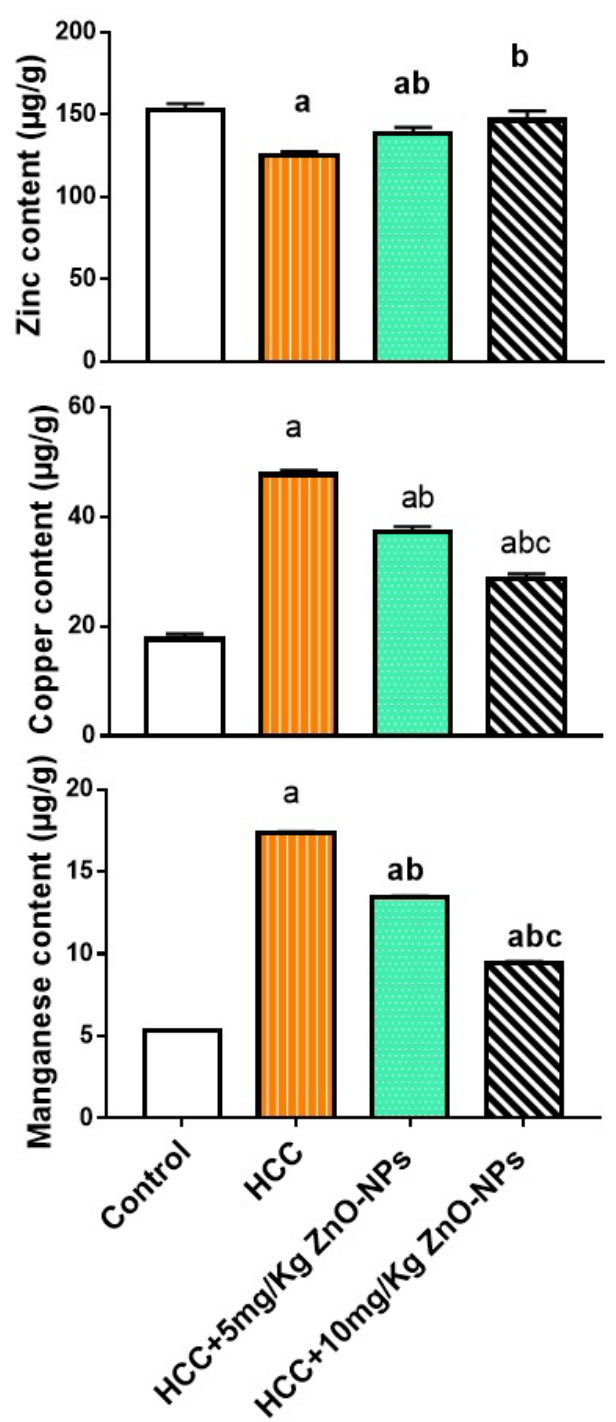

Figure 3. Hepatic trace element levels in various groups. (a): significant difference from the control group, (b): significant difference from the HCC group, and (c): significant difference from the $\mathrm{HCC}+5 \mathrm{mg} / \mathrm{Kg} \mathrm{ZnO-NPs} \mathrm{(zinc}$ oxide nanoparticles) group at $p \leq 0.01$. Each value is the mean $\pm \mathrm{SE} ; n=8$.

depletion, MDA production, SOD inhibition, and reactive oxygen species (ROS) generation. Therefore, oxidative stress may be a key route in producing the cytotoxicity of nanoparticles (Yang et al., 2009). Also, the cytotoxic effects of zinc on cancer cells have been reported. Zinc can promote apoptosis or inhibit cell cycle activity and hence it can reduce the growth and metastasis of cancerous cells. Moreover, zinc showed that metabolic effects originate in part from the effects of zinc on inhibition of citrate oxidation which are essential for the synthesis of energetic requirements for the malignant process (Costello and Franklin, 2012). Angiogenesis plays an important role in the advancement of HCC (Poon et al., 2001). VEGF motivates endothelial cell proliferation and vascular permeability (Poon et al., 2001). GPC3 is frequently produced in HCC. Remarkably elevated expression of GPC3 was demonstrated in HCC tumor tissues. Cell surface GPC3 may combine with growth factors which are likely implicated in
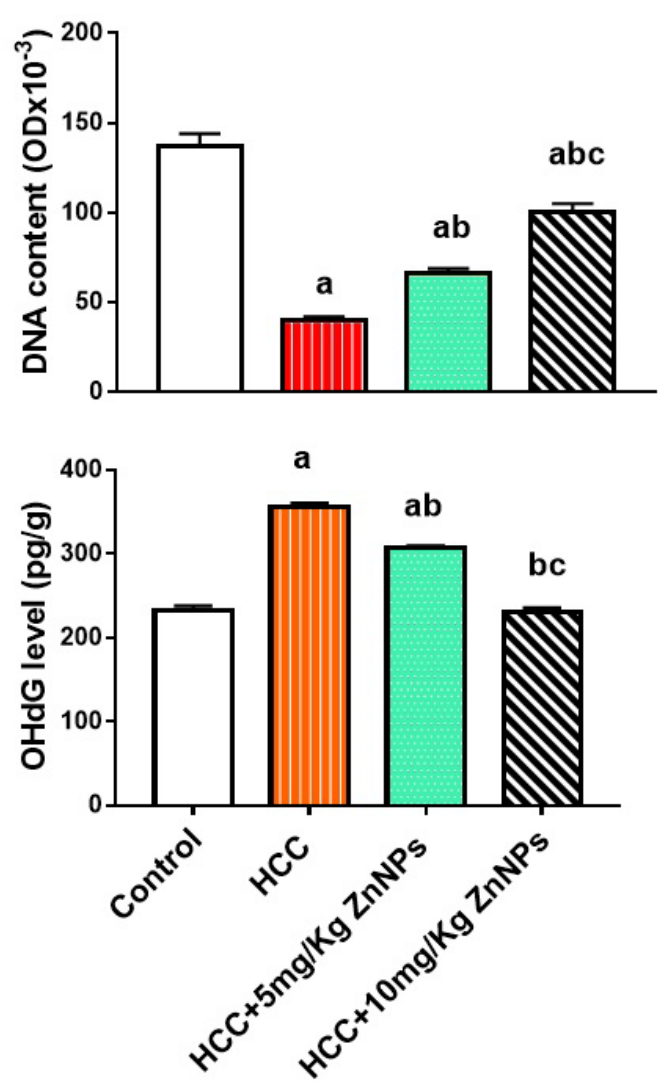

Figure 4. Hepatic DNA (deoxyribonucleic acid) and 8-OHdG (8-hydroxy-2'deoxyguanosine) levels in various groups. (a): significant difference from the control group, (b): significant difference from the HCC group, and (c): significant difference from the $\mathrm{HCC}+5 \mathrm{mg} / \mathrm{Kg} \mathrm{ZnO}-\mathrm{NPs}$ (zinc oxide nanoparticles) group at $p \leq 0.01$. Each value is the mean $\pm \mathrm{SE} ; n=8$.

the rapid development of $\mathrm{HCC}(\mathrm{Wu}, 2015)$. AFP is a tumor sign for HCC and helps in cancer diagnosis (Yi et al., 2013).

Oxidative stress known as an essential agent implicated in the pathogenesis of HCC and ROS is proved to be the main reason for liver cancer ( $\mathrm{Fu}$ and Chung, 2018). Carcinogenesis may proceed if a lack of harmony between oxidative stress and the efficiency of antioxidant defense happens. It appears that the DNA damage is predominantly linked with the initiation process of cancer. It is now well established that ROS can damage DNA and that GSH can protect against this type of damage (Valko et al., 2007). DNA mutation is a decisive step in carcinogenesis and raised levels of oxidative DNA lesions (8-OHdG) have been recognized in many tumors (Guo et al., 2016) Here, rats with HCC exhibited oxidative stress as noticed from an increment of hepatic MDA (a signal of lipid peroxidation) and a reduction of GSH or CoQ10 levels. The significant increase in lipid peroxidation may be the elucidation for the liver damage noticed in this study. The participation of lipid peroxidation in the cell membrane damage due to chain reaction is well affirmed (Ayala et al., 2014). Administration of $\mathrm{ZnO}-\mathrm{NPs}$ to rats with $\mathrm{HCC}$ in this study opposed oxidative stress as shown by the conservation of antioxidant levels of hepatic GSH, CoQ10, SOD, and lowering of MDA (Oxidized lipids). Moreover, ZnO-NPs treatment to $\mathrm{HCC}$ 


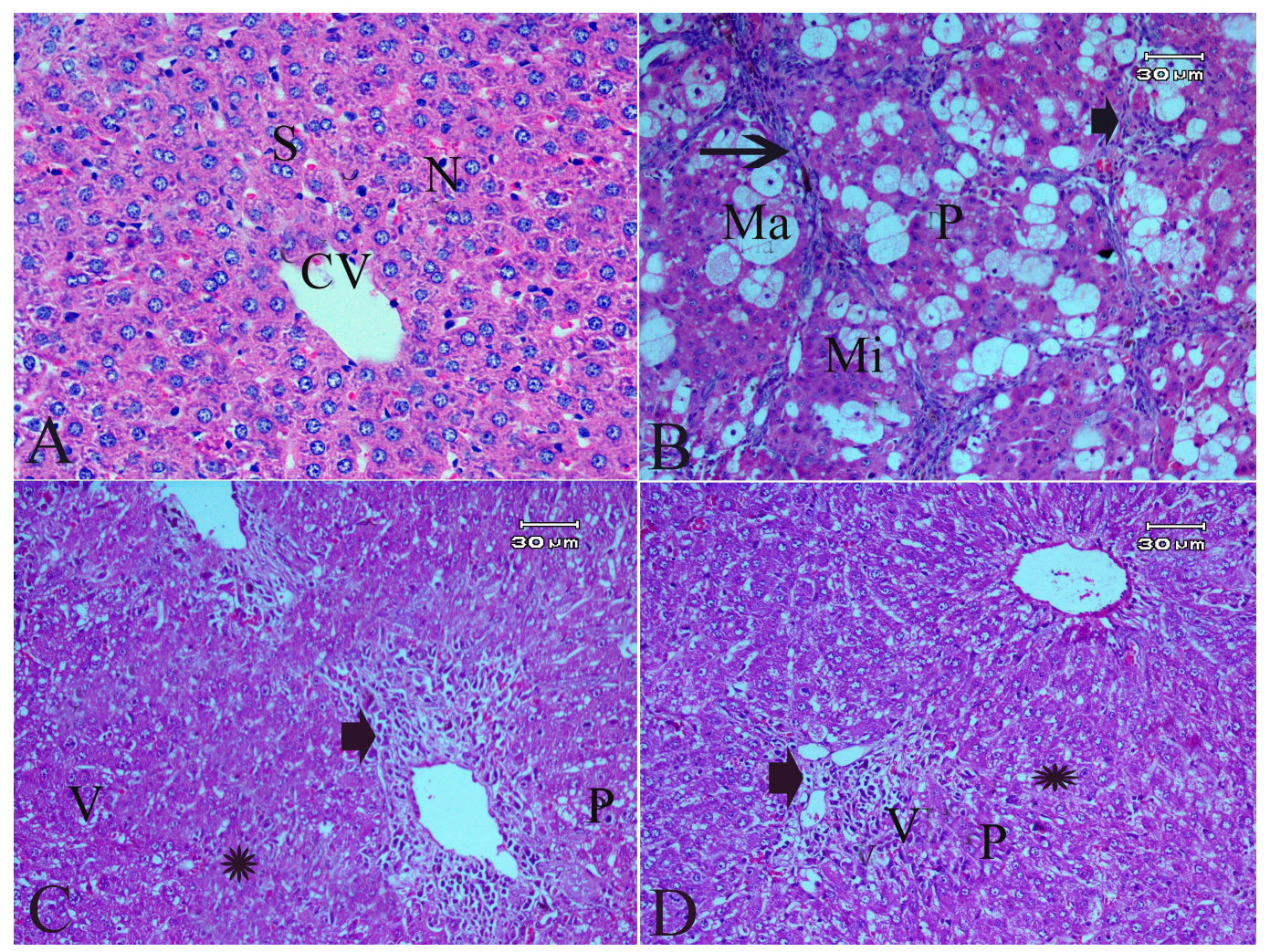

Figure 5. Effect of zinc nanoparticles on liver histopathology of rats with HCC (400×; H\&E stain). The control group showing normal central vein (CV), sinusoids (S), and nucleus (N). (B) The liver of the HCC group showing loss of hepatic lobular architecture, ballooning changes of hepatocytes, pyknotic nuclei (P), macrovesicular (Ma), microvesicular steatosis (Mi), portal tracts extended with massive necrosis (arrowhead), inflammation cell infiltration or fibrous tissue, and periportal and pericellular fibrosis (arrow). (C) The liver of the $\mathrm{HCC}+5 \mathrm{mg} / \mathrm{Kg} \mathrm{Zn-ONPs} \mathrm{group} \mathrm{showing} \mathrm{partly} \mathrm{preserved} \mathrm{hepatic} \mathrm{normal} \mathrm{architecture,} \mathrm{moderate} \mathrm{degrees} \mathrm{of} \mathrm{steatosis}$ (Star), the hepatocytes were still, vacuolated (V), swollen with narrow sinusoids. Inflammation cell infiltration (arrowhead), and portal tracts to pericellular fibrosis were extended with moderate fibrous tissue was observed. (D) The liver of the $\mathrm{HCC}+10 \mathrm{mg} / \mathrm{Kg} \mathrm{ZnO}$-NPs group showing inflammation cell infiltration (arrowhead) and hepatocytes that were still swollen, but they were notably reduced in extent and were less frequent compared to the HCC group whereas microvesicular steatosis (star) was still present in the surrounding liver parenchyma with pyknotic nuclei (P).

rats decreased liver function markers as AST, ALT, and GGT suggesting a decrease in liver pathology. It was reported that $\mathrm{ZnO}$ NPs showed antioxidant activity via scavenging of free radicals (Tettey and Shin, 2019) that may participate in the restoration of the antioxidant system. GSH also inhibited free radical damage, and its decrease is connected with the progression of cancer (Vieira et al., 2011). Additionally, CoQ10 is a vigorous antioxidant that conserves cells from free radical-stimulated oxidative damage (Singh et al., 2007). Since increased levels of ROS have been proposed to enhance the expansion of HCC by motivating DNA and genes changes (Machida et al., 2004), the anticancer activity of $\mathrm{ZnO}-\mathrm{NPs}$ can be attributed to the decrease in 8-OHDG level, a marker for oxidative DNA damage and carcinogenesis (Valavanidis et al., 2009). The decrease in the 8-OHDG level due to treatment of $\mathrm{HCC}$ rats with $\mathrm{ZnO}-\mathrm{NPs}$ can be referred to as the decrease in TNF- $\alpha$ level that enhanced the formation of 8-OHDG through an increase in oxidative stress (Wheelhouse et al., 2003). Another interpretation for the anticancer of $\mathrm{ZnO}-\mathrm{NPs}$ is related to the reduction of $\mathrm{NO}$ level in the liver that motivated tumor angiogenesis by elevation of the blood flow in the tumor cells and so induces tumor development and growth (Oktem et al., 2004). Furthermore, zinc is implicated in some vital cellular processes related to cancer progress through the stimulation of DNA repair and hindering apoptosis (Ho, 2004).
Our results demonstrated an anti-inflammatory activity of $\mathrm{ZnO}-\mathrm{NPs}$ as proved by a reduction in CRP, IL- 6 , and TNF- $\alpha$ levels in the HCC rat model. The antioxidant and anti-inflammatory characteristics of ZnO-NPs were mentioned (Nagajyothi et al., $2015)$ in the lipopolysaccharide animal model. It was suggested that $\mathrm{ZnO}-\mathrm{NPs}$ lowered hepatic damage induced by thioacetamide by reducing IL-6 and lipid peroxidation levels (Bashandy et al., 2018). IL-6 could be believed a convenient tumor marker for HCC particularly with AFP (Porta et al., 2008). Inflammatory cells are tumor developers that make a suitable environment for tumor growth, DNA damage, angiogenesis, and metastasis (Allin et al., 2009). Our results illustrated fibrosis in the liver of rats with HCC. The development of HCC involves several stages and includes inflammation-associated fibrosis and cirrhosis via activation of hepatic stellate cells by cytokines and ROS, produced in the injured liver (Huang et al., 2014). Serum CRP- (an inflammatory marker) is upregulated in HCC (Carr et al., 2018).

ZnO-NPs can modulate alteration of lipid metabolism and carbohydrate metabolism observed in HCC rats and reduce the elevation of cholesterol, triglycerides, and LDL observed in $\mathrm{HCC}$ rats. It has been reported that zinc given to diabetic patients led to the decrease in lipid parameters (cholesterol, LDL, and triglycerides) and the increase in HDL-cholesterol (El-Ashmony et al., 2012). The present results suggested that $\mathrm{ZnO}-\mathrm{NPs}$ affect 


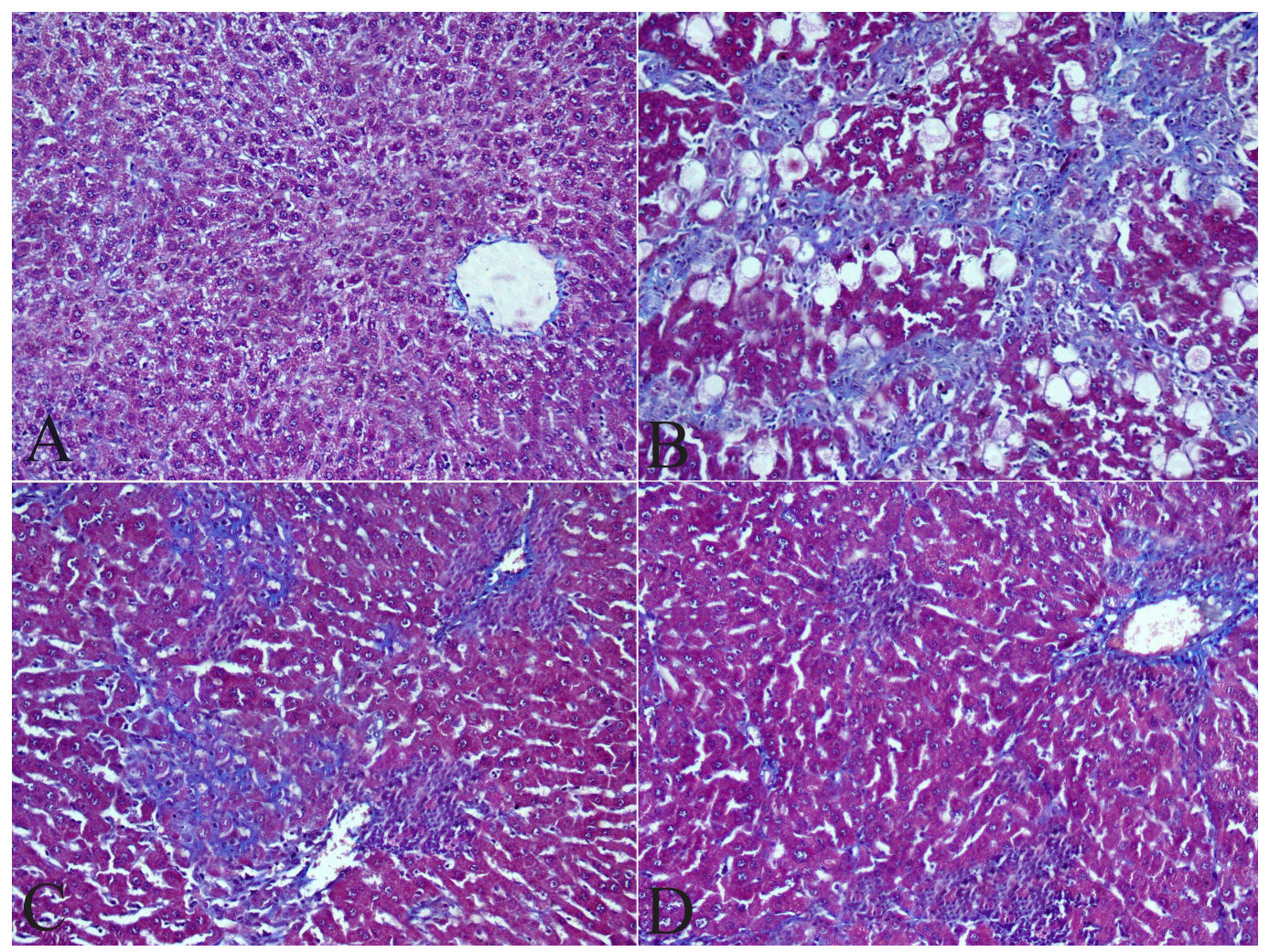

Figure 6. Effect of zinc nanoparticles on liver fibrosis (400×; Masson's trichrome stain). (A) Liver section of control rat showing no collagen fibers. (B) Liver section of the HCC group showing marked increased fibrosis, multiple fibrotic nodules, and blue collagen fibers which are seen among periportal and pericellular areas. (C) Liver section of the $\mathrm{HCC}+5 \mathrm{mg} / \mathrm{kg} \mathrm{ZnO}-\mathrm{NPs}$ group showing fewer strand fibers of collagen among periportal and pericellular areas. (D) Liver section of the HCC + $10 \mathrm{mg} / \mathrm{kg} \mathrm{ZnO}-\mathrm{NPs}$ group showing fewer collagen fibers among periportal and pericellular areas.

lipid metabolism indirectly by hindering the elevation of TNF- $\alpha$ level in HCC rats. TNF- $\alpha$ motivates atherogenic pathways through the lessening of HDL production, stimulation of the process of cholesterogenic gene expression, and inhibition of cholesterol elimination (Tacer et al., 2007). Moreover, ZnO-NPs antagonized the decrease in the glucose level, hepatic ATP, and mucopolysaccharides levels. It was reported that zinc can widely modify energetic metabolism and is major in reconditioning the declined energetic metabolism of cellular physiology (Yang et al., 2017).

Trace elements may be engaged in the development of HCC. There is an association between copper, magnesium, and zinc and the severity of cirrhosis or HCC (Arirudran et al., 2014). Here, the hepatic zinc level decreased significantly in the HCC group, while copper and manganese levels increased significantly. Copper was concluded to be elevated in serum patients with liver cirrhosis (Nangliya et al., 2015). The increase in hepatic copper level in HCC rats may be due to the elevation of Ceruloplasmin, a major copper-carrying protein (Pousset et al., 2001). The histopathological changes observed in the HCC group can be attributed to copper accumulation that results in oxidative liver injuries (Hatano et al., 2000) or to a decrease in zinc content that has antioxidant properties (Jarosz et al., 2017). It was observed that the manganese absorption in patients with hepatic cirrhosis is higher than that in normal adults (Takikawa, 1990). The increased manganese level in the liver of HCC may be due to enhancement of its absorption through the intestine. It has appeared that the improved liver structure of HCC rats treated with $\mathrm{ZnO}$-NPs can be explained by the increase in hepatic zinc level and the decrease in hepatic copper or manganese concentrations.

In conclusion, the treatment of $\mathrm{HCC}$ rats with $\mathrm{ZnO}-\mathrm{NPs}$ showed an anticancer effect which may be due to modulation of oxidative stress, metabolic disorders, oxidative damage of DNA, inflammatory markers, and trace elements. Considering the highly specific characteristics of ZnO-NPs and their selectivity and toxicity toward cancer cells may make them a new therapeutic for next-medication cancer treatment. Although ZnO-NPs improve many parameters involved in the development of HCC, some pathological changes were notified in the liver of the $\mathrm{HCC}$ $+\mathrm{ZnO}-\mathrm{NPs}$ groups. These may mean that ZnO-NPs need more modifications to become more effective.

\section{AUTHOR CONTRIBUTIONS}

All authors made substantial contributions to conception and design, acquisition of data, or analysis and interpretation of data; took part in drafting the article or revising it critically for important intellectual content; agreed to submit to the current journal; gave final approval of the version to be published; and agree to be accountable for all aspects of the work. All the authors are eligible to be an author as per the international committee of medical journal editors (ICMJE) requirements/guidelines. 


\section{FUNDING}

This work is financially supported by National Research Centre, Cairo, Egypt.

\section{CONFLICTS OF INTEREST}

The authors report no financial or any other conflicts of interest in this work.

\section{ETHICAL APPROVALS}

Study protocol was approved by National Research Centre (NRC), Egypt with ethical approval No. 19218.

\section{PUBLISHER'S NOTE}

This journal remains neutral with regard to jurisdictional claims in published institutional affiliation.

\section{REFERENCES}

Allin KH, Bojesen SE, Nordestgaard BG. Baseline C-reactive protein is associated with incident cancer and survival in patients with cancer. J Clin Oncol, 2009; 27(13):2217-24.

Arirudran B, Krishnamurthy V, Saraswathy A. Alteration in levels of minerals in DEN induced hepatocellular carcinoma in Wistar Albino Rats. J Appl Pharm Sci, 2014; 4(12):90-4.

Aslam MS, Naveed S, Ahmed A, Abbas Z, Gull I, Athar A. Side effects of chemotherapy in cancer patients and evaluation of patients opinion about starvation based differential chemotherapy. J Cancer Ther, 2014; 5(5):817-22.

Ayala A, Muñoz MF, Argüelles S. Lipid peroxidation: production, metabolism, and signaling mechanisms of malondialdehyde and 4-hydroxy2-nonenal. Oxid Med Cell Longev, 2014; 2014:1-31.

Bashandy SA, Alaamer A, Moussa SAA, Omara EA. Role of zinc oxide nanoparticles in alleviating hepatic fibrosis and nephrotoxicity induced by thioacetamide in rats. Can J Physiol Pharmacol, 2018; 96(4):337-44.

Carr BI,AkkizH, Guerra V, ÜsküdarO, Kuran S, Karaoğullarından Ü, Tokmak S, Ballı T, Ülkü A, Akçam T, Delik A. C-reactive protein and hepatocellular carcinoma: analysis of its relationships to tumor factors. Clin Pract (London, England). 2018; 15:625-34.

Costello LC, Franklin RB. Cytotoxic/tumor suppressor role of zinc for the treatment of cancer: an enigma and an opportunity. Expert Rev Anticancer Ther, 2012; 12(1):121-8.

El-Ashmony SMA, Morsi HK, Abdelhafez AM. Effect of zinc supplementation on glycemic control, lipid profile, and renal functions in patients with type II diabetes: a single blinded, randomized, placebocontrolled, trial. J Biol Agric Health, 2012; 2(6):33-41.

Elsayed EA, Moussa SA, El-Enshasy HA, Wadaan MA. Anticancer potentials of zinc oxide nanoparticles against liver and breast cancer cell lines. J Sci Ind Res, 2020; 79:56-9.

Ferlay J, Soerjomataram I, Dikshit R, Eser S, Mathers C, Rebelo M, Parkin DM, Forman D, Bray F. Cancer incidence and mortality worldwide: sources, methods and major patterns in GLOBOCAN 2012. Int J Cancer, 2015; 136(5):E359-86.

$\mathrm{Fu} \mathrm{Y}$, Chung FL. Oxidative stress and hepatocarcinogenesis. Hepatoma Res, 2018; 4(39):1-8.

Gowda R, Jones NR, Banerjee S, Robertson GP. Use of nanotechnology to develop multi-drug inhibitors for cancer therapy. J Nanomedicine Nanotechnol, 2013; 4(6):184-8.

Guo C, Li X, Wang R, Yu J, Yu J, Ye M, Mao L, Zhang S, Zheng S. Association between oxidative DNA damage and risk of colorectal cancer: sensitive determination of urinary 8-hydroxy-2'-deoxyguanosine by UPLC-MS/MS analysis. Sci Rep, 2016; 6:32581.

Hassan HFH, Mansour AM, Abo-Youssef AMH, Elsadek BEM, Messiha BAS. Zinc oxide nanoparticles as a novel anticancer approach; in vitro and in vivo evidence. Clin Exp Pharmacol Physiol, 2017; 44(2):235-43.
Hatano R, Ebara M, Fukuda H, Yoshikawa M, Sugiura N, Kondo F, Yukawa M, Saisho H. Accumulation of copper in the liver and hepatic injury in chronic hepatitis C. J Gastroenterol Hepatol, 2000; 15(7):786-91.

Ho E. Zinc deficiency, DNA damage and cancer risk. J Nutr Biochem, 2004; 15(10):572-8.

Hsu CC, Lee HC, Wei YH. Mitochondrial DNA alterations and mitochondrial dysfunction in the progression of hepatocellular carcinoma. World J Gastroenterol, 2013; 19(47):8880-6.

Huang JQ, Tao R, Li L, Ma K, Xu L, Ai G, Fan XX, Jiao YT, Ning Q. Involvement of heat shock protein 47 in Schistosoma japonicuminduced hepatic fibrosis in mice. Int J Parasitol, 2014; 44(1):23-35.

Jarosz M, Olbert M, Wyszogrodzka G, Młyniec K, Librowski T. Antioxidant and anti-inflammatory effects of zinc-Zinc-dependent NF- $\mathrm{BB}$ signaling. Inflammopharmacology, 2017; 25(1):11-24.

Karatas F, Karatepe M, Baysar A. Determination of free malondialdehyde in human serum by high-performance liquid chromatography. Anal Biochem, 2002; 311(1):76-9.

Lodovici M, Casalini C, Briani C, Dolara P. Oxidative liver DNA damage in rats treated with pesticide mixtures. Toxicology, 1997; 117(1):55-60.

Machida K, Cheng KTH, Sung VMH, Lee KJ, Levine AM, Lai MM. Hepatitis $\mathrm{C}$ virus infection activates the immunologic (type II) isoform of nitric oxide synthase and thereby enhances DNA damage and mutations of cellular genes. J Virol, 2004; 78(16):8835-43.

Marklund S, Marklund G. Involvement of the superoxide anion radical in the autoxidation of pyrogallol and a convenient assay for superoxide dismutase. Eur J Biochem, 1974; 47(3):469-74.

McNeil SE. Nanoparticle therapeutics: a personal perspective. Wiley Interdiscip Rev Nanomed Nanobiotechnol 2009; 1(3):264-71.

Mullen PJ, Yu R, Longo J, Archer MC, Penn LZ. The interplay between cell signaling and the mevalonate pathway in cancer. Nat Rev Cancer 2016; 16(11):718-31.

Nagajyothi PC, Cha SJ, Yang IJ, Sreekanth TVM, Kim KJ, Shin HM. Antioxidant and anti-inflammatory activities of zinc oxide nanoparticles synthesized using Polygala tenuifolia root extract. J Photochem Photobiol B Biol, 2015; 146:10-7.

Nangliya V, Sharma A, Yadav D, Sunder S, Nijhawan S, Mishra S. Study of trace elements in liver cirrhosis patients and their role in prognosis of disease. Biol Trace Elem Res, 2015; 165(1):35-40.

Oktem G, Karabulut B, Selvi N, Sezgin C, Sanli UA, Uslu R, Yurtseven ME, Omay SB. Differential effects of doxorubicin and docetaxel on nitric oxide production and inducible nitric oxide synthase expression in MCF-7 human breast cancer cells. Oncol Res Featuring Preclin Clin Cancer Ther, 2004; 14(7-8):381-6.

Omri K, Bettaibi A, Najeh I, Rabaoui S, Khirouni K, El Mir, L. Role of annealing temperature on electrical and optical properties of $\mathrm{ZnO}$ nanoparticles for renewable energy applications. J Mater Sci Mater Electron, 2016; 27(1):226-31.

Papadoyannis IN, Samanidou VF, Nitsos CC. Simultaneous determination of nitrite and nitrate in drinking water and human serum by high performance anion-exchange chromatography and UV detection. J Liq Chromatogr Relat Technol, 1999; 22(13):2023-41.

Parikh S, Hyman D. Hepatocellular cancer: a guide for the internist. Am J Med, 2007; 120(3):194-202.

Poon RTP, Ng IOL, Lau C, Zhu LX, Yu WC, Lo CM, Fan ST, Wong J. Serum vascular endothelial growth factor predicts venous invasion in hepatocellular carcinoma: a prospective study. Ann Surg, 2001; 233(2):227.

Porta C, De Amici M, Quaglini S, Paglino C, Tagliani F, Boncimino A, Moratti R, Corazza GR. Circulating interleukin-6 as a tumor marker for hepatocellular carcinoma. Ann Oncol, 2008; 19(2):353-8.

Pousset D, Piller V, Bureaud N, Piller F. High levels of ceruloplasmin in the serum of transgenic mice developing hepatocellular carcinoma. Eur J Biochem, 2001; 268(5):1491-9.

Schulze A, Harris AL. How cancer metabolism is tuned for proliferation and vulnerable to disruption. Nature, 2012; 491(7424):364-73. 
Sharma M, Reddy DN, Kiat TC. Refractory hypoglycemia presenting as first manifestation of advanced hepatocellular carcinoma. ACG Case Rep J, 2014; 2(1):50-2.

Shen C, James SA, de Jonge MD, Turney TW, Wright PF, Feltis BN. Relating cytotoxicity, zinc ions, and reactive oxygen in $\mathrm{ZnO}$ nanoparticle-exposed human immune cells. Toxicol Sci, 2013; 136(1):12030.

Singh BN, Singh BR, Sarma BK, Singh HB. Potential chemoprevention of N-nitrosodiethylamine-induced hepatocarcinogenesis by polyphenolics from Acacia nilotica bark. Chem Biol Interact, 2009; 181(1):20-8.

Singh U, Devaraj S, Jialal I. Coenzyme Q10 supplementation and heart failure. Nutr Rev, 2007; 65(6):286-93.

Starley BQ, Calcagno CJ, Harrison SA. Nonalcoholic fatty liver disease and hepatocellular carcinoma: a weighty connection. Hepatol, 2010; 51(5):1820-32.

Tacer KF, Kuzman D, Seliskar M, Pompon D, Rozman D. TNF- $\alpha$ interferes with lipid homeostasis and activates acute and proatherogenic processes. Physiol Genomics, 2007; 31(2):216-27.

Takikawa S. Changes in serum $\mathrm{Zn}, \mathrm{Cu}, \mathrm{Se}$, and $\mathrm{Mn}$ levels in patients with chronic liver diseases and hepatocellular carcinoma. J Clin Biochem Nutr, 1990; 8(2):153-64.

Teerlink T, Hennekes M, Bussemaker J, Groeneveld J. Simultaneous determination of creatine compounds and adenine nucleotides in myocardial tissue by high-performance liquid chromatography. Anal Biochem, 1993; 214(1):278-83.

Tettey CO, Shin HM. Evaluation of the antioxidant and cytotoxic activities of zinc oxide nanoparticles synthesized using Scutellariabaicalensis root. Sci Afr, 2019; 6(e00157):1-7.

Torre LA, Freddie B, Siegel RL, Ferlay J, Lortet-Tieulent J, Jemal A. Global cancer statistics, 2012. CA Cancer J Clin, 2015; 65(2):87108.

Valavanidis A, Vlachogianni T, Fiotakis, C. 8-hydroxy-2'deoxyguanosine (8-OHdG): a critical biomarker of oxidative stress and carcinogenesis. J Environ Sci Health Part C, 2009; 27(2):120-39.

Valko M, Leibfritz D, Moncol J, Cronin MT, Mazur M, Telser J. Free radicals and antioxidants in normal physiological functions and human disease. Int J Biochem Cell Biol, 2007; 39:44-84.

Vieira FGK, Pietro PFD, Boaventura BCB, Ambrosi C, Rockenbach G, Fausto MA, Crippa CG, Silva ELD. Factors associated with oxidative stress in women with breast cancer. Nutr Hosp, 2011; 26:528-36.

Vinardell MP, Mitjans M. Antitumor activities of metal oxide nanoparticles. Nanomaterials, 2015; 5(2):1004-21.

Vizirianakis IS. Nanomedicine and personalized medicine toward the application of pharmacotyping in clinical practice to improve drug-delivery outcomes. Nanomedicine Nanotechnol Biol Med, 2011; 7(1):11-7.

Wang B, Feng W, Wang M, Wang T, Gu Y, Zhu M, Ouyang H, Shi J, Zhang F, Zhao Y, Chai Z. Acute toxicological impact of nano-and submicro-scaled zinc oxide powder on healthy adult mice. J Nanopart Res, 2008; 10(2):263-76.

Wheelhouse NM, Chan YS, Gillies SE, Caldwell H, Ross JA, Harrison DJ, Prost S. TNF- $\alpha$ induced DNA damage in primary murine hepatocytes. Int J Mol Med, 2003; 12(6):889-94.

Wu Y, Liu H, Weng H, Zhang X, Li P, Fan CL, Li B, Dong PL, Li L, Dooley S, Ding HG. Glypican-3 promotes epithelial-mesenchymal transition of hepatocellular carcinoma cells through ERK signaling pathway. Int J Oncol, 2015; 46(3):1275-85.

Yang H, Liu C, Yang D, Zhang H, Xi Z. Comparative study of cytotoxicity, oxidative stress and genotoxicity induced by four typical nanomaterials: the role of particle size, shape and composition. J Appl Toxicol, 2009; 9(1):69-78

Yang X, Wang H, Huang C, He X, Xu W, Luo Y, Huang K. Zinc enhances the cellular energy supply to improve cell motility and restore impaired energetic metabolism in a toxic environment induced by OTA. Sci Rep, 2017; 7(1):1-11.

Yi X, Yu S, Bao Y. Alpha-fetoprotein-L3 in hepatocellular carcinoma: a meta-analysis. Clin Chim Acta, 2013; 425:212-20.

Yoshida T. Determination of reduced and oxidized glutathione in erythrocytes by high-performance liquid chromatography with ultraviolet absorbance detection. J Chromatogr B Biomed Sci Appl, 1996; 678(2):15764

Yubero D, Montero R, Artuch R, Land JM, Heales SJ, Hargreaves IP. Biochemical diagnosis of coenzyme q10 deficiency. Mol Syndromol, 2014; 5(3-4):147-55.

Zekri ARN, Hafez MM, Bahnassy AA, Hassan ZK, Mansour T, Kamal MM, Khaled HM. Genetic profile of Egyptian hepatocellularcarcinoma associated with hepatitis $\mathrm{C}$ virus Genotype 4 by $15 \mathrm{~K}$ cDNA microarray: preliminary study. BMC Res Notes, 2008; 1(1):106.

\section{How to cite this article:}

Bashandy SAE, Ahmed-Farid OAH, Moussa SA, Omara EA, Jaleel GAA, Ibrahim FAA. Efficacy of zinc oxide nanoparticles on HCC-induced biochemical and trace element alterations in rats. J Appl Pharm Sci, 2021; 11(05):108-117. 